\title{
Assessment of the realisation of individual dietary guidelines in patients undergoing haemodialysis treatment in the context of nutrient level and energy requirements
}

\section{Ocena realizacji indywidualnych zaleceń dietetycznych wykazująca stopień pokrycia zapotrzebowania na energię i składniki odżywcze pacjentów leczonych hemodializa}

\author{
Anna Tokarska1,2, Edyta Suliga ${ }^{1}, K^{1}$ laudia Tokarska-Jakubczyk ${ }^{3}$ \\ Institute of Nutrition and Dietetics of Collegium Medicum, Jan Kochanowski University, Kielce, Poland \\ Head of the Department: Prof. Edyta Suliga \\ 2Department of Nutrition, Świętokrzyskie Centrum Onkologii, Kielce, Poland \\ Head of the Department: Prof. Stanisław Góźdź \\ 3PZU Zdowie Department of Artimed Medical Centre, Kielce, Poland \\ Head of the Department: Sebastian Kędzierski MD
}

Key words: haemodialysis, dietary recommendations, diet assessment.

Słowa kluczowe: hemodializa, zalecenia dietetyczne, ocena realizacji diety.

\begin{abstract}
Introduction: Following specified dietary guidelines has a significant influence on the proper course of dialyses, medical examination results, and general well-being of a patient. Starting haemodialysis therapy requires a change in the patient's former diet.

Aim of the research: Analysis of energy consumption and nutrients in a group of patients that participate in haemodialysis therapy, by introducing individual dietary recommendations and assessing their execution in the context of the energy and nutrient requirements within a year of introducing the therapy.

Material and methods: The study was conducted at the Nephrology Department in Wojewódzki Szpital Zespolony in Kielce and at the Dialyses Station at Świętokrzyskie Centrum Onkologii in Kielce. The study involved 48 patients (24 men and 24 women). The average age in men was 57.5812 .15 years (28-77 years), and in women 58.9213 .00 years (34-78 years). The assessment of the daily food rations was conducted by noting the patients' diets for the 3 days preceding the haemodialysis. There was an appropriate amount of energy and nutrients counted for each patient. Moreover, each patient received an individual diet plan. After a year of the study, the analyses of haemodialysed patients' diets were conducted again and compared with the norm.

Results: In the comparison of the nutritional value of the patients' diets at the beginning of the study and a year later, significant differences were noted. They concerned a statistical increase in the percentages of energy, fat, protein, carbohydrates, and phosphorus in the diet.

Conclusions: Haemodialysed patients need to be supervised by a dietician, because they require individually estimated values of energy, nutrients, vitamins, and mineral ingredients.
\end{abstract}

\section{Streszczenie}

Wprowadzenie: Przestrzeganie odpowiednich zaleceń dietetycznych ma duży wpływ na prawidłowy przebieg dializ, dobre samopoczucie i wyniki niektórych badań laboratoryjnych. Rozpoczęcie leczenia za pomocą hemodializy wymaga zmiany diety stosowanej w okresie przeddializacyjnym.

Cel pracy: Analiza spożycia energii i składników odżywczych w badanej grupie pacjentów hemodializowanych przed rozpoczęciem badania, opracowanie indywidualnych zaleceń dietetycznych i ocena realizacji diety wykazująca stopień pokrycia zapotrzebowania na energię i składniki odżywcze po roku prowadzenia badania.

Materiał i metody: Badania przeprowadzono na Oddziale Nefrologii z Ośrodkiem Dializ Wojewódzkiego Szpitala Zespolonego i w Stacji Dializ Świętokrzyskiego Centrum Onkologii w Kielcach. Na przeprowadzenie badań otrzymano zgodę Komisji Bioetycznej przy Świętokrzyskiej Izbie Lekarskiej w Kielcach nr 18/2006 w dniu 12 grudnia 2006 r. Do badania włączono 48 pacjentów (24 mężczyzn i 24 kobiety). Średnia wieku mężczyzn wynosiła 57,58 $\pm 12,15$ roku (28-77 lat), a kobiet 58,92 
$\pm 13,00$ lat (34-78 lat). Ocenę dziennych racji pokarmowych wykonano metodą bieżącego notowania z 3 dni poprzedzających dializy. Uzyskane wyniki porównano z normami żywienia dla osób hemodializowanych. Każdemu pacjentowi wyliczono odpowiednią ilość energii i składników odżywczych i zaplanowano dietę. Po roku prowadzenia badania powtórnie dokonano analizy żywienia hemodializowanych pacjentów i porównano z normami.

Wyniki: Porównując wyniki wartości odżywczej jadłospisów pacjentów na początku i po pierwszym roku badania, odnotowano istotne statystycznie różnice dotyczące zwiększenia średniego udziału energii, białka, tłuszczu, węglowodanów i fosforu w diecie. Istotne różnice wystąpiły również w procencie realizacji normy dla tych samych składników. Analizując spożycie tłuszczu, należy zaznaczyć, że zwiększył się również odsetek WNKT. Badania wykazały, że wartości spożycia witaminy C, tiaminy i ryboflawiny były wyższe w drugiej ocenie jadłospisów, lecz różnice nie były istotne. Oceniając zawartość składników mineralnych po roku badania, stwierdzono, że udział sodu kształtował się na tym samym poziomie, natomiast udział potasu wykazał mniejszą wartość, a zawartość wapnia w diecie była zrealizowana w połowie normy. Zawartość cholesterolu w diecie była wyższa, lecz różnice nie były istotne statystycznie. Zawartość błonnika w racji pokarmowej kształtowało się poniżej poziomu normy zarówno w pierwszej, jak i w drugiej ocenie wartości odżywczej ocenianych jadłospisów, lecz nie była to różnica istotna.

Wnioski: Porównanie wyników przed rozpoczęciem i po rocznym okresie prowadzenia badania wykazało istotnie większy udział energii i większą zawartość składników odżywczych w diecie pacjentów hemodializowanych.

\section{Introduction}

Haemodialysis is the most frequent method of kidney-replacement treatment in patients with a chronic kidney disease. It is a method of purifying blood from the toxic products of metabolism. Kidney-replacement treatment is one of the levels of the chronic disease which deactivates almost every metabolic process and leads to severe deficiencies in nutrients. A relationship between the mortality rate of patients with chronic kidney disease and severe nutrient deficiencies has been confirmed by various studies $[1,2]$. Starting a haemodialysis treatment requires a change in the patient's diet. Following certain dietary guidelines has a great influence on the process of dialyses, blood test results, and the patient's general well-being. Malnutrition is another significant problem that is an outcome of the failure to follow dietary guidelines. A low albumin concentration in the patient's blood results in a higher risk of infection and decreases the survival chances [3-6].

\section{Aim of the research}

The aim of the study was to analyse the energy consumption and the level of nutrients in the group of haemodialysed patients before the study, to prepare individual dietary guidelines, and to assess the execution of these guidelines in the context of covering the energy requirement and nutrients after a year of conducting the study.

\section{Material and methods}

The study was conducted at the Nephrology Department in Wojewódzki Szpital Zespolony in Kielce and at the Dialyses Station at Świętokrzyskie Centrum Onkologii in Kielce. The study was approved by Bioethical Committee in Kielce on 12 December 2006 (18/2006). The patients agreed to the terms and conditions of the study and were aware that they could resign from participating in it at any time.

The study involved 48 patients $(24$ men and 24 women). The average age in men was $57.58 \pm 12.15$ years (28-77 years), and in women $58.92 \pm 13.00$ years (34-78 years). The patients were haemodialysed because of a chronic kidney disease. All the patients qualified to take part in the study were suffering from the $5^{\text {th }}$ level of kidney malfunction, which corresponds to the level at which a $<15 \mathrm{~m} / \mathrm{min} / 1.73 \mathrm{~m}^{2}$ glomerular filtration rate (GFR) downfall was observed.

The definition of the amount of nutrients and energy in patients' daily diets was conducted by noting the patients' diets for the 3 days preceding the haemodialysis. The patients were informed about the way of noting down the amounts of food that they eat. In order to authenticate the data, the patients were equipped with books entitled 'Fotografie produktów i potraw' (Photographs of products and dishes), which illustrated certain portions along with their weight [7]. The results were compiled using a computer programme entitled 'Dieta 2' [8], which is used for the planning and assessment of individual dietary habits. Then the results were compared with the dietary norms for haemodialysed patients $[9,10]$.

The basal metabolic rate index was estimated for each patient using the Harris-Beneditc formula, as well as the physical activity level (PAL) [5]. Based on the biochemical and anthropometric examination results, and with regard to any coexisting diseases, a 7-day diet was planned for each patient. The diet included the norms of the daily amount of energy and nutrients (the individual dietary guidelines, education in the field of healthy diet, the dietician's workload, and the patients' dietary habits have been published in "Problemy Higieny i Epidemiologii" - The Problems of Hygiene and Epidemiology - 2011; 92(1): 77-82, 2008; 89(1): 90-92).

After 12 months, a quantitative assessment of the daily food rations was conducted on the basis of the patients' menus and their notes from the 3 days preceding the haemodialysis. The nutrient value was estimated and compared with the norms for haemodialysed patients $[9,10]$. The nutritional values of the patients' menus at the beginning and at the end of 
the study were compared. The patients who did not realise the dietary norm were given further guidelines. The comparative assessment involved a smaller group of patients, due to the eliminating factors such as transplantation, death, or resignation from participating in the study.

\section{Statistical analysis}

The statistical analysis of the study results was conducted with SPSS 14.0 software for Windows. Average, minimal, and maximal values were marked. Standard variation was also calculated. The statistical significance level was marked at $p=0.05$. To compare the variables in the dependent groups, Student's $t$-test and $U$ Mann-Whitney test were used. In the independent groups, a Wilcoxon pair sequence test was used.

\section{Results}

Analysis of the energy and nutrients in the group of haemodialysed patients at the start of the study, before preparing dietary guidelines

The role of energy, protein, fat, and carbohydrates in patients' diets

The analysis of the average energy and nutrient input taken from 3 subsequent diet plans indicated that the average energetic value of the diet equalled $1571.68 \pm 437.35 \mathrm{kcal}$. There was a significant variation in the energy percentage. The energetic value of the meals varied from 653.60 to $2763.99 \mathrm{kcal}$. The average energy input was significantly higher in men - 1736.98 $\pm 457.99 \mathrm{kcal}$ - than in women $-1406.38 \pm 352.25 \mathrm{kcal}$ ( $p=0.0158)$. Depending on the respondents' gender, there were significant differences in their diets, apart from the polyunsaturated fatty acids (PUFA). In the case of protein, men had greater consumption (68.61 $\pm 20.06 \mathrm{~g})$ than women $(55.14 \pm 14.31 \mathrm{~g} ; p=0.0198)$. Men also consumed greater amounts of fat in their diet $(58.60 \pm 21.74 \mathrm{~g})$ than in the case of women $(45.50$ $\pm 16.24 \mathrm{~g} ; p=0.0288$ ). The low percentage of unsaturated fatty acids in patients' diets is worth noting -6.07 $\pm 2.85 \mathrm{~g}$ (range: $1.59-15.16 \mathrm{~g}$; there was no difference between the group of men and women, $p=0.0712$ ). The percentage of carbohydrates was significantly different in the groups, and their average consumption equalled, correspondingly, $244.48 \pm 66.81 \mathrm{~g}$ in men and $207.47 \pm 56.04 \mathrm{~g}$ in women $(p=0.0221)$.

The percentage of energy and nutrient norm realisation in the examined diet plans did not show any significant differences between the groups of men and women for all values. The average percentage of the norm realisation was $73.88 \pm 19.86 \%$ for energy, $82.65 \pm 23.23 \%$ for protein, the consumption of fat in both groups was realised, on average, in 73.71 $\pm 27.55 \%$, and the norm percentage for carbohydrates equalled $79.83 \pm 26.18 \%$. Deficiency in the realisation of the norm was around $20 \%$.

\section{The percentage of vitamins in the patients' diets}

The analysis of vitamins $\mathrm{C}, \mathrm{B}_{1}$ (thiamines), $\mathrm{B}_{2}$ (riboflavins), and folic acid in patients' diets did not indicate differences; only in the case of thiamine were there differences between the groups. The percentage of thiamine in the diet was higher in men $(1.16 \pm 0.41 \mathrm{mg})$ than in women $(0.92 \pm 0.27 \mathrm{mg})$ ( $p=0.0478)$, and the percentage of vitamins and folic acid indicated that the percentage of vitamin $\mathrm{C}$ was below the norm and equalled $82.11 \pm 46.13 \%$. The percentage of thiamine and riboflavin was satisfactory - it equalled almost $100 \%$. There were significant differences between the groups: for thiamine, it was $21.81 \%(p=0.0379)$, and for riboflavin $16.33 \%$ $(p=0.0199)$. The percentage of folic acid equalled $63.15 \pm 17.69 \%$ of the norm.

The percentage of mineral ingredients in patients' diets

Appropriate consumption of mineral ingredients in diets of haemodialysed patients is a vital element of the treatment. Having analysed the percentages of them in patients' diets, one can note that only in the case of magnesium were significant differences between the groups noted. Similarly to the previous results, also in this case the percentages were higher in men $(211.55 \pm 55.52 \mathrm{mg})$ than in women (182.55 $\pm 56.32 \mathrm{mg})(p=0.0478)$, and the percentage of the norm realisation indicated that only the percentage of phosphorus was similar to the haemodialysis dietary norms and equalled $92.38 \pm 26.78 \%$. From the perspective of nutrition during haemodialysis, it is a satisfactory result. However, the value of calcium in the diet turned out to be disturbing - it equalled only $39.27 \pm 18.32 \%$. The percentage of sodium was similarly low $-116.51 \pm 37.31 \%$.

\section{The percentage of cholesterol and dietary fibre in patients' diets}

The studies show that the consumption of these nutritions in the diet was below the norm. The average cholesterol percentage equalled $250 \pm 112.54 \mathrm{mg}$, which equalled $82.02 \%$ of the norm. The value of cholesterol in men's diet reached $287.31 \pm 132.55 \mathrm{mg}$, (92.13\%), and in women $213.81 \pm 73.92 \mathrm{mg}$ (70.91\%). It may suggest reduced cholesterol consumption in women, but the difference was not significant. For dietary fibre, this value equalled $15.81 \pm 4.19 \mathrm{~g}$, and the percentage of its realisation in the diet reached $63.58 \%$, which indicates very low consumption of products rich in fibre. There were no significant differences in fibre consumption between the groups. 


\section{Assessment of the nutritional value of patients' diets after 1 year}

Proper nutrition in haemodialysed patients leads to better treatment results. That is why, after one year of preventative nutritional intervention, patients diet plans were analysed once again. Patients' diet plans from 3 subsequent days were analysed to calculate the nutritional value of the consumed products and, consequently, to check the execution of dietary guidelines.

The results have shown a significant difference between the groups in protein consumption $(p=0.0148)$, where the average for men was $77.71 \pm 10.02 \mathrm{~g}(60.89$ $100.7 \mathrm{~g})$, and for women $70.3 \pm 14.85 \mathrm{~g}(53.26-107.06 \mathrm{~g})$. There were no significant differences noted in the remaining parameters. There were no differences between the groups of men and women in terms of norm realisation for the particular nutritions.

The average percentages of the norm realisation were as follows: for macroelements (protein, fat, PUFA, carbohydrates) $89.90-98.32 \%$, for mineral ingredients (sodium, potassium, calcium, magnesium) $45.37-117.7 \%$, for vitamins (C, thiamine, riboflavin and folic acid) $77.89-118.70 \%$, and for cholesterol and dietary fibre, correspondingly $-106.73 \%$ and $68.69 \%$.

The comparison of the nutrient value results of patients' diet plans at the beginning and at the end of the study

Statically significant differences in the energy percentage were noted in the analysis of patients' diet plans at the beginning and at the end of the study (Table 1). It should be noted that significant differences also occurred in the norm realisation percentage for these ingredients, apart from phosphorus (Table 2).

It was noted that the energetic value of the meals significantly increased and equalled 1910.76 $\pm 299.56 \mathrm{kcal}$, while before the study this value was $1573.05 \pm 432.65 \mathrm{kcal}(p=0.0001)$. This is illustrated also by the average norm realisation percentage, which equalled $73.88 \pm 19.86 \% \mathrm{kcal}$ at the beginning, while during the study it rose and reached 95.65 $\pm 15.15 \%$ ( $p<0.0001)$ after 12 months.

The percentage of protein in the diet increased from $62.31 \pm 19.36 \mathrm{~g}$ to $73.87 \mathrm{~g}(p=0.0018)$, which equalled $98.32 \pm 21.44 \%$ of its consumption in the diet. With regard to the fat percentage in the diet, it is worth noting that its consumption increased from $50.15 \pm 20.14 \mathrm{~g}$ to $66.44 \pm 13.91 \mathrm{~g}(p=0.0003)$, which was also indicated by its norm percentage - from $73.71 \pm 27.55 \%$ to $94.44 \pm 21.44 \%(p=0.0003)$.

It is also worth noting that the percentage of fat consumption, that PUFA equalled $93.65 \pm 43.91 \%$ in the end, while earlier it was only $85.97 \pm 39.93 \%$. A similar growth tendency was presented by carbohydrates: their value equalled $232.35 \pm 59.99 \mathrm{~g}$ at the beginning. The second study showed a growth up to $271.53 \pm 46.98 \mathrm{~g}(p=0.0009)$.

The data in Table 2 indicate that the norm of vitamin $\mathrm{C}$, thiamine, and riboflavin consumption was higher in the second diet plan assessment, but the difference was not significant. The percentage of vitamin C equalled $98.74 \%$, for thiamine it was $101.95 \%$, and the percentage of riboflavin was above the norm and reached $118.7 \%$. Folic acid, however, was below the norm and equalled $77.89 \%$. The percentage of it in the diet was higher, and it equalled $63.15 \%$ of the norm.

The analysis of patients' diets after the first year of the study and the percentages of sodium, potassium, calcium, phosphorus, and magnesium in the diet show that the percentage of sodium stayed on the same level and equalled $2330.16 \pm 746.25 \mathrm{mg}$ before the study and $2344.15 \pm 786.52 \mathrm{mg}$ after a year, but it did not exceed the norm (116.71\%). Because of the limited percentage of sodium in the haemodialysed patients' diets [9], the assessment of it was positive, while its norm was realised only in $88.42 \%$. It has been emphasized that the patients' diet was poor in calcium; however, its realisation norm was higher in the second study ( $45.37 \pm 15.60 \%)$, i.e. it reached half of the norm. The percentage of phosphorus turned out to be within the norm, which was assessed positively in the context of the haemodialysed patients' diets [10]. At the beginning, the level of phosphorus was $930.38 \pm 277.89 \mathrm{mg}$, while after a year it reached $1044.58 \pm 221.79 \mathrm{mg}$. The difference was significant $(p=0.0476)$. The percentage of the realisation norm equalled $92.38 \%$ at the beginning of the study and $104.46 \%$ after a year. The percentage of magnesium in the diet indicated a rising tendency, but it was not statistically significantly different $(p=0.7681)$. The first value equalled $78.25 \%$, while the second reached $85.05 \%$. It was placed slightly below the norm.

Tables 1 and 2 indicate that at the beginning of the study, the percentage of cholesterol and dietary fibre was $246.90 \mathrm{~g}(82.26 \%)$, while after a year it rose to $288.71 \mathrm{~g}(96.24 \%)$. The realisation of the norm was satisfactory, but the difference was not significant.

Having analysed the fibre percentage in the diet, it is worth assuming that the average dietary fibre consumption was below the norm in both studies it reached, correspondingly, $63.58 \%$ and $68.69 \%$, and the difference was not significant.

The nutritional value in men's diet throughout a yet was not significantly different (Table 3 ). The percentage of the norm realisation (Table 4), however, indicated 2 significant differences, i.e. for energy and protein. At the beginning, the percentage of energy was $74.31 \%$, and after a year it was $87.91 \%$ $(p=0.0138)$. The percentage of the norm realisation in the case of protein was at the limit of statistical significance ( $p=0.0501)$. At the beginning its value was $81.98 \%$, and after a year it was $94.40 \%$ of the norm. 
Table 1. Comparison of average percentages of energy and mineral ingredients in patients' diets between the beginning and the first year of the study (a period of 1 year)

\begin{tabular}{|c|c|c|c|}
\hline Parameter & $\begin{array}{l}\text { Patients in general } \\
N=36 \\
\text { Mean } \pm \text { SD } \\
\text { The beginning of the study }\end{array}$ & $\begin{array}{l}\text { Patients in general } \\
\qquad N=36 \\
\text { Mean } \pm \text { SD } \\
\text { After } 1 \text { year of the study }\end{array}$ & $P$-value \\
\hline Energy [kcal] & $1573.05 \pm 432.65$ & $1910.76 \pm 299.56$ & 0.0001 \\
\hline Protein [g] & $62.31 \pm 19.36$ & $73.87 \pm 13.08$ & 0.0018 \\
\hline Fat [g] & $50.15 \pm 20.14$ & $66.44 \pm 13.91$ & 0.0003 \\
\hline PUFA [g] & $5.96 \pm 2.87$ & $6.25 \pm 2.80$ & ST \\
\hline Carbohydrates [g] & $232.35 \pm 59.99$ & $271.53 \pm 46.98$ & 0.0009 \\
\hline Vitamin C [mg] & $66.47 \pm 39.18$ & $83.93 \pm 51.47$ & ST \\
\hline Thiamine [mg] & $1.07 \pm 0.40$ & $1.12 \pm 0.23$ & ST \\
\hline Riboflavin [mg] & $1.22 \pm 0.40$ & $1.43 \pm 0.61$ & ST \\
\hline Folic acid [ $\mu \mathrm{g}]$ & $205.17 \pm 50.27$ & $233.67 \pm 101.98$ & ST \\
\hline Sodium[mg] & $2330.16 \pm 746.25$ & $2354.15 \pm 786.52$ & ST \\
\hline Potassium [mg] & $2275.95 \pm 662.56$ & $2210.49 \pm 537.48$ & ST \\
\hline Calcium [mg] & $395.28 \pm 197.94$ & $453.66 \pm 156.02$ & ST \\
\hline Phosphorus [mg] & $930.38 \pm 277.89$ & $1004.58 \pm 221.79$ & 0.0476 \\
\hline Magnesium [mg] & $204.64 \pm 59.63$ & $212.62 \pm 56.99$ & ST \\
\hline Cholesterol [mg] & $246.90 \pm 109.02$ & $288.71 \pm 121.75$ & ST \\
\hline Dietary fibre [g] & $16.20 \pm 4.37$ & $17.17 \pm 4.55$ & ST \\
\hline
\end{tabular}

ST - statistically insignificant.

Table 2. Comparison of the norm realisation percentage for energy and mineral ingredients in patients' diets between the beginning and the first year of the study (a period of 1 year)

\begin{tabular}{|c|c|c|c|}
\hline Parameter & $\begin{array}{l}\text { Patients in general } \\
\qquad=36 \\
\text { Mean } \pm \text { SD } \\
\text { The beginning of the study }\end{array}$ & $\begin{array}{l}\text { Patients in general } \\
\qquad \begin{array}{l}N=36 \\
\text { Mean } \pm \text { SD }\end{array} \\
\text { After } 1 \text { year of the study }\end{array}$ & $P$-value \\
\hline Energy (\%) & $73.88 \pm 19.86$ & $95.65 \pm 15.15$ & 0.0001 \\
\hline Protein (\%) & $82.65 \pm 23.23$ & $98.32 \pm 21.44$ & 0.0018 \\
\hline Fat (\%) & $73.71 \pm 27.55$ & $94.44 \pm 18.76$ & 0.0003 \\
\hline PUFA (\%) & $85.97 \pm 39.93$ & $93.65 \pm 43.91$ & ST \\
\hline Carbohydrates (\%) & $79.83 \pm 26.18$ & $89.90 \pm 14.92$ & 0.0009 \\
\hline Vitamin C (\%) & $116.51 \pm 37.31$ & $117.71 \pm 77.89$ & ST \\
\hline Thiamine (\%) & $82.11 \pm 46.13$ & $98.74 \pm 60.58$ & ST \\
\hline Riboflavin (\%) & $94.85 \pm 33.57$ & $101.95 \pm 23.03$ & ST \\
\hline Folic acid (\%) & $99.71 \pm 32.88$ & $118.70 \pm 49.86$ & ST \\
\hline Sodium (\%) & $63.15 \pm 17.69$ & $77.89 \pm 33.99$ & ST \\
\hline Potassium (\%) & $89.80 \pm 24.79$ & $88.42 \pm 21.50$ & ST \\
\hline Calcium (\%) & $39.27 \pm 18.32$ & $45.37 \pm 15.60$ & ST \\
\hline Phosphorus (\%) & $92.38 \pm 26.78$ & $104.46 \pm 22.18$ & ST \\
\hline Magnesium (\%) & $78.25 \pm 22.69$ & $85.05 \pm 22.79$ & ST \\
\hline Cholesterol (\%) & $82.26 \pm 37.07$ & $96.24 \pm 40.58$ & ST \\
\hline Dietary fibre (\%) & $63.58 \pm 17.03$ & $68.69 \pm 18.18$ & ST \\
\hline
\end{tabular}

ST - statistically insignificant. 
Table 3. Comparison of the average energy percentage in men's diets between the beginning and the first year of the study

\begin{tabular}{|c|c|c|c|}
\hline Parameter & $\begin{array}{l}\text { The beginning of the study } \\
\text { Men } \\
N=18 \\
\text { Mean } \pm \text { SD }\end{array}$ & $\begin{array}{l}\text { After a year of the study } \\
\text { Men } \\
N=18 \\
\text { Mean } \pm \text { SD }\end{array}$ & $P$-value \\
\hline Energy [kcal] & $1734.51 \pm 457.76$ & $1976.73 \pm 270.89$ & ST \\
\hline Protein [g] & $68.74 \pm 21.12$ & $77.71 \pm 10.02$ & ST \\
\hline Fats [g] & $57.36 \pm 22.81$ & $68.94 \pm 12.42$ & ST \\
\hline PUFA [g] & $6.80 \pm 2.96$ & $6.32 \pm 2.07$ & ST \\
\hline Carbohydrates [g] & $250.39 \pm 59.51$ & $281.69 \pm 44.03$ & ST \\
\hline Vitamin C [mg] & $60.71 \pm 34.81$ & $85.85 \pm 60.23$ & ST \\
\hline Thiamine [mg] & $1.18 \pm 0.47$ & $1.20 \pm 0.27$ & ST \\
\hline Riboflavin [mg] & $1.28 \pm 0.46$ & $1.47 \pm 0.72$ & ST \\
\hline Folic acid [ $\mu \mathrm{g}]$ & $212.18 \pm 53.44$ & $251.90 \pm 126.14$ & ST \\
\hline Sodium [mg] & $2561.04 \pm 680.17$ & $2626.09 \pm 655.95$ & ST \\
\hline Potassium [mg] & $2391.36 \pm 687.45$ & $2196.85 \pm 517.98$ & ST \\
\hline Calcium [mg] & $399.98 \pm 235.06$ & $433.04 \pm 168.08$ & ST \\
\hline Phosphorus [mg] & $1007.21 \pm 311.81$ & $1048.33 \pm 199.97$ & ST \\
\hline Magnesium [mg] & $217.81 \pm 58.05$ & $297.85 \pm 248.03$ & ST \\
\hline Cholesterol [mg] & $275.06 \pm 128.53$ & $345.58 \pm 121.32$ & ST \\
\hline Dietary fibre [g] & $16.14 \pm 3.76$ & $17.06 \pm 4.02$ & ST \\
\hline
\end{tabular}

ST - statistically insignificant.

Table 4. Comparison of the realisation norm for energy and nutrients in men's diets between the beginning and the first year of the study

\begin{tabular}{|c|c|c|c|}
\hline Parameter & $\begin{array}{l}\text { The beginning of the study } \\
\text { Men } \\
N=18 \\
\text { Mean } \pm \text { SD }\end{array}$ & $\begin{array}{c}\text { After a year of the study } \\
\text { Men } \\
N=18 \\
\text { Mean } \pm \text { SD }\end{array}$ & $P$-value \\
\hline Energy (\%) & $74.31 \pm 19.15$ & $87.91 \pm 12.69$ & 0.0138 \\
\hline Protein (\%) & $81.98 \pm 26.86$ & $94.40 \pm 11,49$ & 0.0501 \\
\hline Fat (\%) & $76.80 \pm 31.24$ & $93.05 \pm 19.34$ & ST \\
\hline PUFA (\%) & $87.12 \pm 37.97$ & $80.97 \pm 26.49$ & ST \\
\hline Carbohydrates (\%) & $82.00 \pm 30.14$ & $90.31 \pm 15.87$ & ST \\
\hline Vitamin C (\%) & $71.42 \pm 40.95$ & $101.00 \pm 70.85$ & ST \\
\hline Thiamine (\%) & $107.03 \pm 42.56$ & $108.74 \pm 24.67$ & ST \\
\hline Riboflavin (\%) & $106.47 \pm 38.54$ & $122.70 \pm 59.69$ & ST \\
\hline Folic acid (\%) & $70.73 \pm 17.81$ & $83.97 \pm 42.05$ & ST \\
\hline Sodium (\%) & $128.05 \pm 34.00$ & $123.90 \pm 35.74$ & ST \\
\hline Potassium (\%) & $95.65 \pm 27.49$ & $87.87 \pm 20.87$ & ST \\
\hline Calcium (\%) & $40.00 \pm 23.50$ & $43.30 \pm 16.80$ & ST \\
\hline Phosphorus (\%) & $100.72 \pm 31.18$ & $104.83 \pm 19.99$ & ST \\
\hline Magnesium (\%) & $85.62 \pm 23.82$ & $84.56 \pm 23.37$ & ST \\
\hline Cholesterol (\%) & $91.69 \pm 42.84$ & $107.17 \pm 43.73$ & ST \\
\hline Dietary fibre (\%) & $64.57 \pm 15.05$ & $68.23 \pm 16.09$ & ST \\
\hline
\end{tabular}

ST - statistically insignificant. 
Table 5. Comparison of the average percentage of energy and nutritional ingredients in women's diets at the beginning and after a year of the study

\begin{tabular}{|c|c|c|c|}
\hline Parameter & $\begin{array}{l}\text { At the beginning of the study } \\
\text { Women } \\
N=18 \\
\text { Mean } \pm \text { SD }\end{array}$ & $\begin{array}{l}\text { After a year of the study } \\
\text { Women } \\
N=18 \\
\text { Mean } \pm \text { SD }\end{array}$ & $P$-value \\
\hline Energy [kcal] & $1411.59 \pm 347.33$ & $1844.79 \pm 319.61$ & 0.0001 \\
\hline Protein [g] & $55.88 \pm 15.43$ & $70.03 \pm 14.85$ & 0.0018 \\
\hline Fats [g] & $42.94 \pm 14.32$ & $63.94 \pm 15.19$ & 0.0001 \\
\hline PUFA [g] & $5.12 \pm 2.59$ & $6.73 \pm 3.42$ & ST \\
\hline Carbohydrates [g] & $214.32 \pm 56.39$ & $261.37 \pm 48.86$ & 0.0041 \\
\hline Vitamin C [mg] & $72.23 \pm 43.34$ & $82.01 \pm 42.65$ & ST \\
\hline Thiamine [mg] & $0.96 \pm 0.28$ & $1.03 \pm 0.22$ & ST \\
\hline Riboflavin [mg] & $1.5 \pm 0.32$ & $1.38 \pm 0.48$ & ST \\
\hline Folic acid $[\mu \mathrm{g}]$ & $198.16 \pm 47.36$ & $215.43 \pm 69.26$ & ST \\
\hline Sodium [mg] & $2145.31 \pm 823.34$ & $2230.44 \pm 854.03$ & ST \\
\hline Potassium [mg] & $2160.54 \pm 634.83$ & $2224.13 \pm 570.98$ & ST \\
\hline Calcium [mg] & $390.58 \pm 159.27$ & $474.27 \pm 144.80$ & ST \\
\hline Phosphorus [mg] & $853.54 \pm 221.96$ & $1040.82 \pm 247.50$ & 0.0150 \\
\hline Magnesium [mg] & $191.46 \pm 59.86$ & $226.79 \pm 89.57$ & ST \\
\hline Cholesterol [mg] & $218.73 \pm 79.16$ & $283.69 \pm 100.51$ & 0.0388 \\
\hline Dietary fibre [g] & $16.27 \pm 5.01$ & $17.29 \pm 5.13$ & ST \\
\hline
\end{tabular}

ST - statistically insignificant.

Table 6. Comparison of the realisation norm for energy and nutrients in women's diets between the beginning and the first year of the study

\begin{tabular}{|c|c|c|c|}
\hline Parameter & $\begin{array}{l}\text { At the beginning of the study } \\
\text { Women } \\
N=18 \\
\text { Mean } \pm \text { SD }\end{array}$ & $\begin{array}{l}\text { After a year of the study } \\
\text { Women } \\
\begin{array}{c}N=18 \\
\text { Mean } \pm \text { SD }\end{array}\end{array}$ & $P$-value \\
\hline Energy (\%) & $73.06 \pm 22.12$ & $94.21 \pm 17.32$ & 0.0011 \\
\hline Protein (\%) & $80.82 \pm 23.13$ & $103.78 \pm 28.01$ & 0.0048 \\
\hline Fat (\%) & $63.14 \pm 23.31$ & $97.11 \pm 18.49$ & 0.0006 \\
\hline PUFA (\%) & $80.85 \pm 40.95$ & $106.37 \pm 54.08$ & 0.0138 \\
\hline Carbohydrates (\%) & $75.59 \pm 17.27$ & $90.22 \pm 14.43$ & 0.0014 \\
\hline Vitamin C (\%) & $86.02 \pm 52.35$ & $100.43 \pm 48.75$ & ST \\
\hline Thiamine (\%) & $87.47 \pm 25.26$ & $94.00 \pm 19.58$ & ST \\
\hline Riboflavin (\%) & $95.88 \pm 26.83$ & $115.20 \pm 40.13$ & ST \\
\hline Folic acid (\%) & $66.05 \pm 15.78$ & $71.81 \pm 23.08$ & ST \\
\hline Sodium (\%) & $111.86 \pm 44.49$ & $111.52 \pm 42.70$ & ST \\
\hline Potassium (\%) & $87.53 \pm 25.71$ & $89.96 \pm 23.13$ & ST \\
\hline Calcium (\%) & $38.42 \pm 16.17$ & $47.81 \pm 14.82$ & 0.0312 \\
\hline Phosphorus (\%) & $85.76 \pm 22.81$ & $104.54 \pm 25.43$ & 0.0190 \\
\hline Magnesium (\%) & $77.71 \pm 24.18$ & $86.65 \pm 23.05$ & ST \\
\hline Cholesterol (\%) & $72.51 \pm 27.15$ & $84.59 \pm 35.95$ & ST \\
\hline Dietary fibre (\%) & $65.84 \pm 20.38$ & $69.85 \pm 20.82$ & ST \\
\hline
\end{tabular}

ST - statistically insignificant. 
There have been no significant differences noted in the group of men as far as the remaining parameters were concerned.

In the analysis of the nutritional value of the diet in women at the beginning of the study and after 1 year (Table 5) a significant disproportion was noted. The percentages of energy, protein, fat, PUFA, carbohydrates, phosphorus, and cholesterol in the diet were statistically increased. It was noted that the energetic value of the meals increased, and it reached, on average, $1844.79 \pm 319.61 \mathrm{kcal}$, while before the study it was $1411.59 \pm 347.33 \mathrm{kcal}(p=0.0001)$. It is illustrated by the average norm realisation percentage (Table 6), which was $73.06 \pm 22.12 \% \mathrm{kcal}$ for energy, and within a year it rose to $94.21 \pm 17.32 \%$ ( $p=0.0011)$. The average increase of protein in the diet is also worth emphasizing; it increased from $55.88 \pm 15.43 \mathrm{~g}$ to $70.03 \pm 14.85 \mathrm{~g}$, which equalled $103.78 \pm 28.01 \%$ of its consumption $(p=0.0048)$. The value of fat in the diet increased significantly, from $42.94 \pm 14.32 \mathrm{~g}$ to $63.94 \pm 15.19 \mathrm{~g}$ ( $p=0.0001)$, which was also indicated by the higher norm realisation process at the beginning - 63.14 $\pm 23.13 \%$ and after a year $97.11 \pm 18.49 \%(p=0.0006)$. The value of PUFA was $106.37 \pm 54.08 \%$, and beforehand the realisation was significantly lower 80.85 $\pm 40.94 \%$ ( $p=0.0138$ ). Similarly to other components, carbohydrates presented a growing trend; the value before the study was $214.32 \pm 5.39 \mathrm{~g}$, and then it rose to $261.37 \pm 48.86 \mathrm{~g}$ and presented a significant difference $(p=0.0041)$.

A consequence of increased protein consumption is the increase of phosphorus - its percentage in the diet equalled $853.54 \pm 221.96 \mathrm{mg}$ before the study, and then it increased to $1040.82 \pm 247.50 \mathrm{mg}(p=0.0150)$, which was slightly above the norm. Its value reached $104.54 \%$. Similarly to the previous case, the increased fat consumption in women's diets indicated a significantly higher value of cholesterol, where it equalled $283.69 \pm 100.51 \mathrm{mg}(p=0.0388)$ after a year of the study, and it constituted $84.59 \%$ of the norm. Despite the increase the value stayed within the norm. A significant difference ( $p=0.0312$ ) was noted between the nutritional value of calcium, where its realisation in the diet increased to $47.81 \%$. However, it constituted only half of the daily demand for this substance.

\section{Discussion}

Dietary treatment is based on using the diet as a way of preventing complications and maintaining health. Keeping an adequate nutrition level is a counterpart of the therapeutic process. A therapeutic diet involves certain modifications depending on the disease, the amount of nutrients, and their preparation by definition. It also highlights nutrients that need to be limited or eliminated. A human being needs a proper amount of all the nutrients in order to function properly. These nutrients are chemical compounds that are used by the human body as a building material, a source of energy, and to maintain life functions. Selective deficiencies or vitamin and mineral ingredient excess are frequently observed. They are often accompanied by metabolic and hormonal disorders.

In selected cases, strict adherence to the dietary guidelines may significantly reduce the need of taking medications. The benefits of proper secondary prevention may reduce the treatment costs $[3,6,11-14]$.

A study analysing the amount of energy and nutrients in the examined group of haemodialysed patients at the beginning of the study and after one year was conducted in the context of the approach to nutrition in this group of patients.

\section{Analysis of the nutritional value of patients' diet plans at the beginning of the study \\ - before the education started - and an assessment of adherence to guidelines after a year of dietary intervention}

The dietary guidelines for haemodialysed patients suggest daily consumption of 30 to 35 calories per a kilogram of body weight $[9,10,15]$. On the basis of these guidelines, individual energy requirements were calculated for each patient. In the first analysis, the percentage of energy in the diet was, on average, $74 \%$, and after a year it increased significantly and reached 95\% of the norm. Similar results were obtained in a study conducted by Kucharska et al., in which low energy consumption was found in $61 \%$ of patients [16].

Nutrients are another important element when comparing the effects of dietary intervention. The percentage of protein in haemodialysed patients' diets equalled, on average, $82.65 \%$ at first, while after a year the results increased to $98.32 \%$ of the norm.

Appropriate energy supply is inevitable for the full usage of protein included in the diet. It allows one to maintain the level of the body proteins [15]. Having started the dialysotherapy, it is essential to increase the percentage of protein in the diet up to $1.0-1.3 \mathrm{~g} / \mathrm{kg} / \mathrm{day}$ in haemodialysed patients who suffer from a loss of amino acids with a dialysate of 1-4 g/day and of protein 3-15 g/day [13]. Another Polish study has shown that daily food rations in women aged 26-40 years deliver, on average, $88.6 \mathrm{~g}$ of protein, which covers the daily requirements for this nutrient. In the remaining age groups the percentage of protein in the diet was too low [17]. In the case of permanent lack of protein, the synthesis of biologically active compounds such as protein hormone enzymes, or antibodies, decreases. As a consequence, the body mass also becomes lower, and the burning of endogenous protein causes permanent damage to the organism $[6,18]$.

In the context of the mentioned studies concerning fat consumption in the analysed diet plans, it is worth remarking that the percentage of this nutrient increased within a year. Before the study, the 
percentage of fact consumption constituted $73.7 \%$ of the norm, while in the second analysis it increased up to $94.5 \%$. In the context of these values, it is necessary to pay attention to the value of PUFA, which was $93.65 \pm 43.91 \%$, while in the end it was lower at $85.97 \pm 39.93 \%$. In the women's diets, this value was especially high; it constituted $106.4 \%$, while at the beginning it was only $90.85 \%$. Wyszomierska et al. analysed the diets of 38 haemodialysed patients on the basis of their diet journals or interviews concerning their nutrition within the last $24 \mathrm{~h}$. The analysis indicated a high percentage of fat in the diet (especially in women), as well as overly high consumption of saturated acids (SFA) for all the participants. The level of monounsaturated fatty acids (MUFA) was satisfactory in all the participants, whereas the level of PUFA was below the norm [19].

Carbohydrates are another nutritional component that was analysed in the study. Also in this case, a growing trend was observed. The percentage of carbohydrates in patients' diets increased by $10 \%$ and equalled $89.9 \%$. The growth in carbohydrate consumption was significantly different, which resulted in greater energy percentage in the diet after 1 year of the study. Similar results were described by Wyszomirska et al., who noted that the energy obtained from carbohydrates constituted around 100\% of the norm [19].

One of the most significant causes of this deficiency is low levels of vitamins in the diet, disturbed vitamin absorption, and vitamin loss caused by haemodialysis. It seems that the amount of this loss is not affected by the type of a dialysis membrane that is used (high-flux vs. low-flux) [20-23]. In the study, the percentage of vitamins dissolvable in water was assessed twice - at the beginning of the study and after 1 year of dietary intervention. Vitamin $\mathrm{C}$ was the first to be assessed, and its daily consumption in all the patients equalled 66.47 $\pm 39.18 \mathrm{mg}$, and then it increased to $83.93 \pm 51.41 \mathrm{mg}$ The percentage value of the second assessment was $98.74 \%$, which constituted the full realisation norm for this vitamin. The increase of vitamin $C$ percentage in men's diets is worth noting - their daily consumption was, on average, $85.85 \pm 60.23 \mathrm{mg}$ and it reached around $100 \%$ of the norm, increasing by $30 \%$ during one year of the study. In the study conducted by Kucharska et al., the assessment of dietary guidelines in haemodialysed patients indicated that women aged 26-65 years and men aged 41-65 years consumed an appropriate amount of vitamin C. A deficiency in vitamin $C$ consumption occurred in the case of men aged below 25 years, and its excessive dose was consumed by men aged $26-40$ years and women who were more than 65 years old [24]. A dialysate loss of, on average, 80-280 mg during each haemodialysis increases the risk of vitamin $\mathrm{C}$ loss. However, consuming large doses of this vitamin on a daily basis (250-500 mg/day) might increase the vitamin $\mathrm{C}$ concentration and make it exceed the norm. It is worth remembering that excessive doses of vitamin C (> $250 \mathrm{mg} /$ day) escalate oxalosis by increasing the otherwise high oxalic acid concentration in blood [17].

Vitamin $B_{1}$ (thiamine) is another vitamin that is assessed in patients' diets. While analysing the percentage of this vitamin it is worth remarking that during both assessments (at the beginning of the study and after 1 year) the consumption of it was within the norm. In the group of men, the difference in vitamin $B_{1}$ consumption was not significant - it increased from $107.3 \%$ to $108.74 \%$, while in women the value was significantly higher, constituting $87.47 \%$ of the norm at the beginning and $94.00 \%$ after 1 year. This result is positive, because thiamine is normally eluted during haemodialysis. However, various sources indicate different concentration decrease percentages of this vitamin during a single haemodialysis - from $6 \%$ to $82 \%$ [20]. Comparing the outcomes of this study with the results of others, it is worth noting that the consumption that covers the norm was also indicated in a study by Kucharska et al. [16]. Małgorzewicz et al. [3] stated, however, that vitamin $B_{1}$ consumption was fairly low in comparison with the average consumption recommendations for this vitamin.

Vitamin $\mathrm{B}_{2}$ (riboflavin) is another vital ingredient that was assessed during the study. Its value was above the norm and equalled, on average, $118.7 \%$. The consumption of this vitamin was especially high in the group of men, at $106.47 \%$, while after a year this value increased to $122.70 \%$; in both cases, the values exceeded the recommended daily consumption norm. Such a high value might be caused by increased consumption of meat and milk in both groups. These assumptions were confirmed by the surveys concerning dietary habits. Another reason behind the increased riboflavin consumption may be the change of diet from one low in protein to an individually planned high-protein diet.

The results indicating the folic acid concentration in the blood serum, erythrocytes, and tissues of haemodialysed patients vary in the delivered data. The tissue deficiencies of vitamins might occur even if the folic acid concentration in blood remains within the norm. It happens because the blood serum of patients with kidney dysfunction blocks the transport of the vitamin into the cells [17]. The deficiency of folate in the diet occurs frequently in the whole population, and in the group of haemodialysed patients it reaches up to $100 \%$ [22-26]. Molecules of this vitamin are loosely bonded to the plasma protein, which leads to a significant loss during haemodialysis. The concentration of folic acid was reported to fall by $37 \%$ after a single haemodialysis [19]. The available data confirm that folic acid supplementation of $1 \mathrm{mg} / \mathrm{day}$ prevents its deficiency in haemodialysed patients [15]. 
An important aspect of the folic acid consumption analysis was the deficiency of this vitamin both before and after taking dietary intervention in both groups of patients. A comparative analysis of the results showed that the percentage of folic acid was well below the norm and it equalled $77.89 \%$, which was still greater that the previous value of $63.15 \%$. Comparing these values with the results of other studies was not possible because no similar study was found. It should be emphasized that the deficiency of vitamins dissolvable in water is a long-term process, which starts long before the first clinical symptoms occur. The time needed for the tissue supplies of particular vitamins differs significantly (from several days in the case of vitamin $B_{1}$ to several years in the case of vitamin $B_{12}$ ) [23].

The KDOQI recommendations suggest daily phosphorus consumption of $800-1000 \mathrm{mg} /$ day in haemodialysed patients who have phosphorus concentration higher than $5.5 \mathrm{mg} / \mathrm{dl}[24,25]$. The recommendations of a balanced and diversified diet in haemodialysed patients aim at limiting the amount of phosphorus in the diet, with regard to maintaining an appropriate level of protein at the same time. The latest KDIGO recommendations indicate that including a source of phosphorus in a balanced diet is essential (phosphorus obtained from plant or animal products and from food additives) because the absorption of phosphates in the digestive system depends on their bioavailability. Phosphorus absorption in a diet rich in plant protein is lower $(52 \%)$ than in an animal protein diet (70\%) [26-28]. In the conducted study, a comparison of the phosphorus consumption in the diet showed a growing trend. At the beginning, this value in all patients was, on average, $930.38 \pm 277.89 \mathrm{mg}$, and after 1 year it equalled $1004.58 \pm 221.79 \mathrm{mg}$. This significant difference was clearly visible especially in the group of women, where the percentage of phosphorus increased by $20 \%$, and in the final stage of the study it was $104 \%$ of the norm. Despite the increase of phosphorus in the diet, this result is satisfactory, because, on the one hand, it was minimally higher than the norm, and on the other habd, it indicated increased protein consumption in haemodialysed patients. Phosphorus binding medicines need to be given to haemodialysed patients who consume an appropriate amount of protein, as hyperphosphataemia prevention [9]. In a presentation of their dietary interview results, Szpanowska-Wohn et al. indicate that the majority of patients pay attention to limiting phosphorus in the diet. The authors state that the consumption of phosphorus equalled 600-800 mg, which did not exceed the norm of $1000 \mathrm{mg}$ [29].

The KDOQI recommendations suggest that the total daily consumption of calcium does not exceed $2000 \mathrm{mg}$ in both diet and supplements. One needs to pay attention to the products that are strength- ened with calcium phosphate (which increases the phosphorus consumption) and also to the calcium carbonate and calcium citrate as food-strengthening substances [25]. With regard to the calcium daily consumption norm, it can be stated that the consumption of this nutrient equalled, on average (395.28 \pm 197.94 $\mathrm{mg}$ ), and although the second assessment indicated a higher value $(453.66 \pm 156.02 \mathrm{mg})$, it still constituted $45 \%$ of the norm. After a comparison with other studies $[19,30]$, similar or even lower (around 32\%) values were noted. It should be noted that the calculations were done with no regard to the calcium supplementation that patients received to maintain the calciumphosphoric balance.

The recommended daily consumption of magnesium for the whole population equals $420 \mathrm{mg}$ for men and $320 \mathrm{mg}$ for women. Foods that are rich in magnesium are green vegetables (spinach), wholegrains, nuts, and legumes. There is no need to modify the consumption values of this substance in the group of haemodialysed patients $[25,27]$. In this study, the percentage of magnesium in the diet presented a growing trend, but it was not significantly different. At the beginning the value equalled $78.25 \%$, while after 1 year it was a little higher at $85.05 \%$, but it was below the recommended norm. Similar results were obtained by other authors $[19,30]$, who observed low magnesium consumption in patients' diets.

The KDOQI recommendations suggest a limitation of potassium consumption in haemodialysed patients - it should be reduced to $2000-3000 \mathrm{mg} / \mathrm{day}$ [31]. According to ESPEN, the percentage of this macro element in the daily diet should equal around 2000-2500 mg. A low-potassium diet requires limiting products that are rich in this substance, such as fruit, vegetables, or juices [26]. Products that are low in sodium are, for example: rice, eggs, onions, blueberries, cranberries, grapefruit, melon, mango, pear, peach, pineapple, tangerine, watermelon, carrot, cauliflower, celery, and cucumber. The way of preparing meals is also important in the context of limiting potassium in the diet. The amount can be reduced by using double cooking with no salt - the vegetables need to be chopped, poured with boiling water, soaked for up to an hour, and then cooked until they become soft $[15,32]$. As was indicated in the study, the amount of potassium in the patients' diets did not change throughout the study and equalled around $90 \%$ of the norm without any variations within the referential values. A reason behind this result may be more frequent consumption of small fruit or vegetable portions in the group of women, a quarter of whom declared such a change after receiving the dietary education. Other studies [16] suggest significantly greater potassium consumption. The authors highlight that it equalled, on average, $146 \%$ in women and $171.6 \%$ in men. 
As far as the analysis of dietary fibre consumption is concerned, its daily consumption was below the norm in the first and in the second assessment: correspondingly, it equalled $63.58 \%$ and $68.69 \%$. The patients need to consume an appropriate amount of fibre because it prevents constipations. An optimal amount of fibre in the haemodialysed patients' diet is 20-30 g/day, including the consumption of fibre dissolvable in water, which is around 5-10 g/day [25]. The assessment of the haemodialysed patient's diets indicated that its daily consumption constituted around $1 / 3$ of the daily norm [19]. However, the perfect value is difficult to obtain because this ingredient can be found in fruit and vegetables that are also rich in potassium, the consumption of which should be limited in the haemodialysed patients' diet plans because it carries a risk of hyperkalaemia.

The last ingredient that was analysed was cholesterol. Its daily consumption norm for haemodialysed patients varies from 250 to $300 \mathrm{mg}$ [33]. In this group of patients, disturbances of the lipid balance occur frequently, which is why it is advisable to consume plant fats. In the first assessment, the daily consumption of cholesterol was, on average, $246.9 \pm 109.02 \mathrm{mg}$, while the second assessment indicated its value as $288.71 \pm 121.75 \mathrm{mg}$. In the analysis of the increase of cholesterol value in both men's and women's diets, correspondingly, it increased by $4 \%$ and $12 \%$. It should be noted that the higher value might result from the increased fat consumption after 1 year of the study, which was discussed in the initial part of the discussion. Kidney damage leads to the occurrence of a specific constellation of lipid disturbances. Lipid disturbances, particularly hypercholesterolaemia, are serious cardio-vascular disease facilitators [34-38].

\section{Conclusions}

The analysis of the results at the beginning of the study and after 1 year indicated a significantly higher percentage of energy and higher amount of nutrients in patients' daily diets.

In the group of men, the percentage of realisation of the norm in the case of energy and protein in the assessed diet plans was significantly higher. It is a positive change from the perspective of the haemodialysed patients' nutrition, because proper delivery of energy is necessary for a full use of protein in the diet. The delivery of energy maintains the proper level of body proteins.

In the group of women, the assessment of the diet plans indicated a significant difference in the rise in phosphorus and calcium levels, which resulted from the increased consumption of protein-rich products. Haemodialysed patients who consume appropriate amounts of protein need to use phosphate binders in order to prevent hyperphosphataemia.
Haemodialysed patients need to be supervised by a dietician because they require individually calculated amounts of energy, nutrients, vitamins, and mineral ingredients.

\section{Acknowledments}

Project financed under the program of the Minister of Science and Higher Education called "Regional Initiative of Excellence" in the years 2019-2022, project no. 024/RID/2018/19, amount of financing $11,999,000.00 \mathrm{zł}$.

\section{Conflict of interest}

The authors declare no conflict of interest.

\section{References}

1. Małgorzewicz S. Ocena stanu odżywienia i zasady leczenia niedożywienia w przewlekłej chorobie nerek. Forum Nefrol 2019; 12: 244-248.

2. Beddhu S, Wei G, Chen X, BoucherR, Kiani R, RajD, Chonchol M, Greene T, Murtaugh MA. Association of dietary protein and energy intakes with protein Energy wasting syndrom in haemodialysis patients. Kindey Int Rep 2017; 2: 821-30.

3. Małgorzewicz S. Żywienie w chorobach nerek. In: Dietetyka Kliniczna. Grzymisławski M. PZWL Wydawnictwo Lekarskie, Warszawa 2019; 431-436.

4. Pachocka L. Przewlekła niewydolność nerek. In: Dietetyka. Żywność, żywienie w prewencji i leczeniu. Jarosz M (ed.). Instytut Żywności i Żywienia 2017; 316-321.

5. Ciborowska H. Zalecenia żywieniowe dla pacjentów z przewlekłą niewydolnością nerek w okresie dializacyjnym. In: Dietetyka. Ciborowska H (ed.). PZWL Wydawnictwo Lekarskie, Warsaw 2019: 397-400.

6. Bach A, Janicka G. Ocena wiedzy pacjentów hemodializowanych na temat preferowanej diety. Forum Nefrol 2014; 7: 54-60.

7. Szponar L, Wolnicka K, Rychlik E. Album Fotografii Produktów i Potraw. Instytut Żywności i Żywienia, Warsaw 2000.

8. Charzewska J, Rogalska-Niedźwiedź M, Szponar L, et al. Pakiet Dieta 2 do planowania i bieżącej oceny żywienia indywidualnego. Instytut Żywności i Żywienia Warszawa 2002.

9. Jankowska M, Małgorzewicz S, Kaczkan M, et al. Zaburzenia odżywiania oraz zasady racjonalnego odżywiania u pacjentów leczonych nerkozastępczo. In: Leczenie nerko zastępcze. Rutkowski B (ed.). Czelej, Lublin 2007; 561-569.

10. Czekalski S, Gellert R., Rutkowski B, et al. Leczenie dietetyczne w chorobach nerek. Dlaczego, Komu, Kiedy, Jak? In: Nefroprotekcja. Rutkowski B, Czekalski S, Myśliwiec M (eds.). Czelej, Lublin 2006; 35-56.

11. Cano NJM, Mlolane-Debouit M, Leger J, Heng AE. Assessment of body protein: energy status in chronic kidney disease. Semin Nephrol 2009; 29: 59-66.

12. Rutkowski B, Lichodziejewska-Niemierko M, Grenda R. Raport o stanie leczenia nerkozastępczego w Polsce. Drukonsul, Gdańsk 2008: 7-32.

13. Rydzewski A, Kozłowska L. Żywienie i stan odżywienia w chorobach nerek. In: Choroby Nerek. Myśliwiec M (ed.) PZWL, Warsaw 2008; 433-53. 
14. Kalantar-Zadech K, Abbot KC, Kronenberg F, Anker SD, Horwich TB, Fonarow GC. Epidemiology of dialysis patients and heart failure patients; special review article for the 25 anniversary of the Seminars in Nephrology. Semin Nephrol 2006; 26: 118-133.

15. Caglar K, Fedce L, Dimmitt R. Therapeutic effects of oral nutritional supplementation during haemodialysis. Kidney Int 2002; 62: 1054-9.

16. Fouque D, Vennegoor M, Ter Wee P, Wanner C, Basci A, Canaud B, Haage P, Konner K, Kooman J, MartinMalo A, Pedrini L, Pizzarelli F, Tattersall J, Tordoir J, Vanholder R. EBPG Guideline on Nutrition. Nephrology Dialysis Transplant 2007; 22 (Suppl 2): ii45-ii87.

17. Wojtaszek E, Kacprzak M, Lange J, et al. The short-and long-term impast. Of predialysis education on patient outcomes-Polish perspective. Poster in the Congress of the International Society of peritoneal Dialysis, Istambul 2008.

18. Lange J, Wojtaszek E. Program edukacji pacjentów z przewlekła chorobą nerek. Forum Nefrol 2011; 4: 47-50.

19. Rutkowski B, Małgorzewicz S, Łysiak-Szydłowska W z Grupa Ekspertów. Stanowisko dotyczace rozpoznawania oraz postępowania w przypadku niedożywienia dorosłych chorych z przewlekła choroba nerek. Forum Nefrol 2010; 3: 138-142.

20. Kucharska E, Bober J, Bogacka A, Woś M. Ocena żywienia pacjentów z przewlekłą niewydolnością nerek leczonych hemodializą. Bromat Chem Toksykol 2008; 41: 161-167.

21. Grzegorzewska A. Żywienie w chorobach nerek. In: Żywienie Człowieka Zdrowego i Chorego. Grzymisławski M, Gawęcki J (eds.). PWN, Warsaw 2010; 288-297.

22. Romejko-Ciepielewska K, Niemczyk S. Anoreksja u chorych z przewlekłą niewydolnością nerek, wpływ czynników hormonalnych. Nefrol Dializoter Pol 2009; 13: 79-85.

23. Wyszomierska A, Pukar J, Myszkowska-Ryciak J. Okres dializoterapii a sposób żywienia pacjentów ze schyłkową niewydolnością nerek. Państwowy Zakład Higieny 2009; 60: 289-292.

24. Jankowska M, Storoniak H, Rutkowski P. Zaburzenia gospodarki witamin rozpuszczalnych $\mathrm{w}$ wodzie $\mathrm{u}$ pacjentów hemodializowanych. Forum Nefrol 2011; 1: 5-13.

25. Heine J, Domröse U, Westphal S, Luley C, Neumann KH, Dierkes J. Washout of water-soluble vitamins of homocysteine during haemodialysis: effect of high-flux and lou-flux dialyser membranes. Nephrology 2008; 13: 384-389.

26. Arslan Y, Kiziltan G. Nutrition-related cardiovascular risk factors in haemodialysis patients. J Ren Nutr 2010; 20 185-92.

27. Jankowska M. Zapotrzebowanie na witaminy i mikroelementy w przewlekłej chorobie nerek. Forum Nefrol 2019; 12: $275-277$

28. National Kidney Foundation. K/DOQI clinical practice guidelines for bone metabolism and disease in chronic kidney disease. Am J Kidney Dis 2003; 42: S1-S201.

29. Kaczkan M. Zasady żywienia w okresie leczenia za pomoca hemodializy. Forum Nefrol 2019; 12: 265-268.

30. Parpia AS, Goldstein MB, Arcand J, Cho F, L'Abbé MR, Darling PB. Sodium-reduced meat and poultry products contain a significant amnount of potassium from food additives. J Acad Nutr Diet 2018; 118: 878-885.

31. Li L, Streja A, Rhee CM, Mehrotra R, Soohoo M, Brunelli SM, Kovesdy CP, Kalantar-Zadeh K. Hypomagnese- mia and mortality in incident haemodialysis patients. Am J Kidney Dis 2015; 66: 1047-1055.

32. Ketteler M, Block GA, Evenepoel P, Fukagawa M, Herzog CA, McCann L, Moe SM, Shroff R, Tonelli MA, Toussaint ND, Vervloet MG, Leonard MB. Executive summary of the 2017 KDIGO Chronic Kidney Disease-Mineral and Bone Disorder (CKD-MBD) Guideline Update: what's changed and why it matters. Kidney Int 2017; 92: 26-36.

33. Szpakowska-Wohn A, Kolarczyk E, Lang-Młynarska D. Ocena realizacji zaleceń dietetycznych przez pacjentów ze schyłkową niewydolnością nerek leczonych dializoterapią. Probl Hig Epidemiol 2006; 87: 221-227.

34. Rzeszotarski J, Walasek I, Ligocki P. Analiza spożycia wapnia, fosforu i magnezu $\mathrm{w}$ diecie chorych $\mathrm{z}$ przewlekła niewydolnością nerek leczonych hemodializami. J Elem 2005; 10: 1009-1016.

35. Kidney Disease Outcomes Quality Initiative (K/DOQI). $\mathrm{K} / \mathrm{DOQI}$ clinical practice guidelines for the management of hypertension and antihypertensive agents in chronic kidney diease. Am J Kidney Dis 2004; 43 (5 Suppl 1): S1S290.

36. Dąbrowski P, Olszanecka-Glinianowic M, Chudek J. Żywienie w przewlekłej chorobie nerek. Endokrynol Otył Zab Przem Mat 2011; 7: 227-239.

37. Bawa Sa'eed, Gajewska D, Lange E. Wpływ dietoterapii na metabolizm tłuszczu u pacjentów z niewydolnością nerek. Probl Lek 2004; 43: 49-54.

38. Włodarek D. Lange A. Żywienie w przewlekłej niewydolności nerek w okresie leczenia zachowawczego. Probl Lek 2006; 45: 265-266.

\section{Address for correspondence:}

\section{Anna Tokarska PhD}

Institute of Nutrition and Dietetics

Collegium Medicum

Jan Kochanowski University

ul. IX Wieków Kielc 19, 25-317 Kielce

Phone: +48795170663

E-mail: annatokarska@onet.com.pl 